\title{
MANAJEMEN PENDIDIK DAN TENAGA KEPENDIDIKAN DI MADRASAH ALIYAH NEGERI KOTA YOGYAKARTA
}

\author{
Jauharotul Muniroh, Muhyadi \\ Manajemen Pendidikan PPs UNY, Universitas Negeri Yogyakarta \\ jauharotulmuddassir@gmail.com,muhyadi@uny.ac.id
}

\begin{abstract}
Abstrak
Penelitian ini bertujuan untuk mendeskripsikan sistem manajemen sumber daya manusia terkait tentang perencanaan, perekrutan, penempatan dan pengembangan pendidik dan tenaga kependidikan di Madrasah Aliyah Negeri Kota Yogyakarta. Penelitian ini menggunakan pendekatan kualitatif dengan jenis fenomenologi. Hasil penelitian sebagai berikut (1) perencanaan pendidik dan tenaga kependidikan honorer dengan mengusulkan dari madrasah ke Kantor Wilayah Kementerian Agama, dengan menggunakan tiga analisis yaitu melalui analisis kebutuhan, analisis jabatan, analisis beban kerja, sehingga mampu melakukan analisis kelebihan dan kekurangan; (2) perekrutan pendidik dan tenaga kependidikan honorer dengan menentukan kualifikasi penerimaan sehingga diperoleh pendidik yang berkompeten sesuai dengan mata pelajaran yang diampu; sedangkan tenaga kependidikan honorer yang memiliki skill dan keahlian yang dibutuhkan; (3) penempatan pendidik mengacu pada prinsip the right man on the right place akan tetapi masih terdapat mismatch sebesar 10\% antara latar belakang pendidikan dengan mata pelajaran yang diampu; (4) kegiatan pengembangan pendidik dan tenaga kependidikan meliputi pendidikan dan pelatihan berupa bimtek, spiritual quantum learning, studi lanjut, pengembangan diri melalui musyawarah guru mata pelajaran, kegiatan pengajian dan pembinaan.
\end{abstract}

Kata kunci: manajemen, pendidik dan tenaga kependidikan.

\section{MANAGEMENT OF TEACHERS AND EDUCATION PERSONNEL IN MADRASAH ALIYAH NEGERI YOGYAKARTA}

\author{
Jauharotul Muniroh, Muhyadi \\ Manajemen Pendidikan PPs UNY, Universitas Negeri Yogyakarta \\ jauharotulmuddassir@gmail.com,muhyadi@uny.ac.id
}

\begin{abstract}
This study aims to determine the human resources management system in terms of planning, recruitment, placement and development of teachers and education personnel of madrasah aliyah negeri (MAN) in Yogyakarta. This study is using a qualitative approach with phenomenology type. The results of this study indicate that: (1) planning, honorary teachers and education personnel with the proposal from the bottom up, or from madrassas to the Regional Office of the Ministry of Religion Affairs using three kinds of analysis: needs analysis, job analysis, and workload analysis to be able to analyze the advantages and disadvantages; (2) recruiting honorary teachers and education personnel by determining the requirements for acceptance in order to obtain a competent educator in accordance with the subject matter and honorary education personnel who have the skills and expertise needed; (3) the placement of educators applying the principle of the right man on the right place, although there is a mismatch of 10\%; (4) developing activities of teachers and education personnel including education and training in the form of technical assistance, spiritual quantum learning, further studies, selfdevelopment through Subject Matter Teacher Forum, pengajian activities, and coaching.
\end{abstract}

Keywords: management, teachers and education personnel 


\section{Pendahuluan}

Perubahan pendidikan dilatarbelakangi oleh kemajuan ilmu pengetahuan dan teknologi khususnya teknologi informasi, hal ini merupakan tantangan bagi kehidupan di masa depan. Namun, pada sisi lain menjadi sebuah harapan dan sekaligus ancaman bagi bangsa Indonesia yang belum siap menghadapinya. Agar bisa survive dalam menghadapi era ini, diperlukan prasyarat yakni kemampuan berkompetisi secara global dalam meningkatkan kualitas sumber daya manusia. Dalam pembentukkan sumber daya yang berkualitas, keberadaan pendidikan menjadi faktor utama yang harus mendapatkan perhatian serius semua pihak. Perubahan pendidikan juga berimbas pada cara berpikir bangsa Indonesia. Salah satu institusi yang menjadi harapan seluruh masyarakat (khususnya umat Islam) di Indonesia, perlu diupayakan peningkatan kualitas sumber daya manusia khususnya dalam lembaga pendidikan berupa madrasah. Sunhaji (2008, p. 4) "salah satu faktor yang menjadi penyebab lemahnya daya saing madrasah adalah kondisi sumber daya manusia yang ada di madrasah".

Kualitas sumber daya manusia di lingkungan madrasah masih jauh dari harapan. Baik pendidik maupun tenaga kependidikan yang kemampuannya di bawah standar kualitas minimum, masih terdapat pendidik yang mismatch dalam bidang mata pelajaran yang diampu dan mayoritas para pendidik dan tenaga kependidikan di lingkungan madrasah adalah lulusan institusi agama (IAIN/ STAIN), sesuai pendapat Maimun \& Fitri (2010, p.7) "persoalan tenaga kependidikan, pada madrasah ne- geri maupun swasta belum begitu menggembirakan, berdasarkan data bahwa sebagian besar guru madrasah berasal dari IAIN/ STAIN/PTAIS."

Madrasah merupakan perkembangan institusi pendidikan Islam awal (pesantren atau surau) yang memiliki keseimbangan visi, yaitu visi keduniawian (penguasaan ilmu pengetahuan \& teknologi) dan visi keakhiratan. Madrasah juga dipandang lebih komprehensif dibandingkan pendidikan umum yang dirasa kurang memenuhi tuntutan kebutuhan khususnya spritual siswa. Oleh karena itu, madrasah sebagai bagian dari penyelenggaraan pendidikan nasional, saat ini juga dituntut mampu melakukan penyelenggaraan pendidikan yang sesuai dengan standar nasional pendidikan yang sudah ditetapkan. Kemajuan pembangunan di berbagai sektor kehidupan membutuhkan sumber daya manusia yang berkualitas. Proses penerimaan masyarakat terhadap lulusan pendidikan makin ketat dan biasanya menggangap lulusan sekolah umum lebih unggul dibandingkan dengan madrasah. Hal ini diikuti dengan perubahan sikap masyarakat yang semakin selektif dalam memilih lembaga pendidikan. Bagi madrasah situasi ini tidak memberi pilihan lain untuk meningkatkan kualitas pendidikan yang dikembangkan. Namun, mengenai lulusan madrasah masih belum bisa dibanggakan, baik intelektual maupun spiritualnya. Dari segi intelektual, banyak lulusan madrasah yang prestasinya di bawah sekolah umum berdasarkan standar Nilai Ujian Nasional (NUN). Hal tersebut bisa dilihat pada tabel.1 dari hasil prestasi akademik yaitu perolehan NUN dari peringkat 1 sampai 3 masih diraih oleh sekolah umum.

Tabel 1. Nilai UN SMA/MA di Yogyakarta

\begin{tabular}{ccccccc}
\hline Ranking & $\begin{array}{c}\text { Nama Sekolah } \\
(2010 / 2011)\end{array}$ & Nilai & $\begin{array}{c}\text { Nama Sekolah } \\
(2011 / 2012)\end{array}$ & Nilai & $\begin{array}{c}\text { Nama sekolah } \\
(2012 / 2013)\end{array}$ & Nilai \\
\hline 1 & SMA N 3 Yogya & 50,60 & SMA N 1 Yogya & 49,32 & SMA N 1 Yogya & 51,26 \\
2 & SMA N 1 Yogya & 48,76 & SMA N 5 Yogya & 48,43 & SMA N 3 Yogya & 51,24 \\
3 & SMA N 7 Yogya & 46,73 & SMA N 3 Yogya & 49,80 & SMA N 5 Yogya & 49,87 \\
\hline
\end{tabular}


Dari Tabel 1 terlihat bahwa dari aspek prestasi di dalam Negeri, NUN madrasah relatif masih rendah dibandingkan sekolah umum, sehingga tidak mengalami peningkatan yang signifikan dari tahun ke tahun. Dari dunia usaha muncul keluhan bahwa lulusan yang memasuki dunia kerja belum memiliki kesiapan kerja yang baik. Lembaga pendidikan berkualitas dapat melahirkan lulusan yang berkualitas, lulusan yang berkualitas juga dapat dengan mudah memasuki jenjang pendidikan diatasnya sampai dalam rangka memasuki dunia kerja sebagaimana diharapkan.

Madrasah Aliyah Negeri I dan II Yogyakarta merupakan madrasah unggulan baik dalam bidang sains maupun agama, yang ditunjukkan dengan diperolehnya beberapa prestasi baik dalam tingkat daerah maupun nasional. Hal ini merupakan hasil dari kerja keras para stakeholders madrasah. Bukan hanya prestasi saja yang bisa dibanggakan, beberapa kegiatan keagamaan di Madrasah Aliyah Negeri I dan II Yogyakarta juga mendukung dalam pengembangan spritual diri siswa. Madrasah juga difasilitasi baik sarana maupun prasarana, perlengkapan dan begitu pula stakeholders baik dalam maupun luar madrasah juga ikut berpartisipasi dan mendukung kegiatan pembelajaran dan keagamaan.

Berangkat dari permasalahan di MAN di Kota Yogyakarta juga masih terdapat pendidik yang masih mismatch dengan latar belakang pendidikan, terdapat perangkapan bagi guru yang masih kekurangan jam mengajar, pembagian tugas pendidik dan tenaga kependidikan yang belum merata, sehingga masih ada guru yang mengalami kelebihan jam mengajar dan kekurangan jam mengajar. Sehingga perlu dilakukan penelitian tentang Manajemen Pendidik dan Tenaga Kependidikan di Madrasah Aliyah Negeri Kota Yogyakarta. Oleh karena itu, diharapkan bagi stakeholders khususnya pendidik dan tenaga kependidikan di Madrasah Aliyah Negeri 1 dan II Yogyakarta mampu meningkatkan kualitas pendidikan. Agar dalam proses belajar mengajar berjalan dengan lancar dan mampu meningkatkan antusias belajar peserta didik. Apalagi dengan kemajuan sistem teknologi informasi dan komunikasi sekarang ini, khususnya pendidik dan tenaga kependidikan dituntut dan perlu ditingkatkan kompetensi dalam menunjang tercapainya visi dan misi madrasah tersebut.

Manajemen pendidikan terdiri dari dua istilah, yaitu manajemen dan pendidikan. Kata manajemen berasal dari bahasa Latin, yaitu manus yang berarti tangan, dan agere yang berarti melakukan. Kata tersebut digabung menjadi managere yang dalam bahasa Inggris dalam bentuk kata benda adalah management. Certo \& Certo (2012, p. 7) mengungkapkan "as used most commonly in this text, management is the process of reaching organizational goals by working with and through people and other organizational resources". Manajemen merupakan seluruh bagian informasi yang melengkapi wawasan tentang bagaimana mengelola. Istilah manajemen juga dapat merujuk pada individu yang membimbing organisasi secara langsung atau karier khususnya untuk tugas membimbing dan mengarahkan orga-nisasi. sedangkan pendidikan menurut Purwanto (2007, p.11) bahwa segala usaha orang dewasa dalam pergaulan dengan anak-anak untuk memimpin perkembangan jasmani dan rohaninya ke arah kedewasaan.

Definisi manajemen pendidikan menurut Castetter (1996, p. 198) bahwa "educational administration is a social proses that take place within the context of social system". Manajemen pendidikan lebih mengarah pada kepentingan sosial, yaitu sebagai suatu proses sosial dan interaksi orang-orang. Sharma (2009, p.1) mengungkapkan "educational management is a field of study and practice concerned with the operation of educational organisations". Manajemen pendidikan merupakan studi lapangan dan praktek yang berfokus pada pemecahan dalam organisasi pendidikan. Freedman, Cooper \& Stumps (1982, p.18) menjelaskan "management education is a potentially important force in societies that are confronted by problems associated with managerial performance". Manajemen pendidikan merupakan kekuatan penting yang potensial dalam masyarakat 
yang diharapkan pada kaitan masalah dengan pencapaian manajerial. Jadi bisa disimpulkan bahwa manajemen pendidikan adalah sebagai seni dan ilmu mengelola sumber daya pendidikan dalam mencapai tujuan pendidikan.

Berdasarkan teori-teori yang dikemukakan para ahli di atas, maka dapat disimpulkan bahwa manajemen pendidikan merupakan suatu bidang garapan terkait proses perencanaan, perekrutan, penempatan dan pengembangan yang salah satunya yaitu pendidik dan tenaga kependidikan. Dalam penelitian ini, difokuskan pada manajemen pendidik dan tenaga kependidikan. Oleh karena itu, dalam mewujudkan pendidik dan tenaga kependidikan yang baik, berkualitas serta memiliki kemampuan (skill), dan profesionalisme, diperlukan manajemen yang baik sehingga mampu mencapai tujuan pendidikan yang sesuai dengan harapan madrasah.

Pendidik dan tenaga kependidikan dalam proses pendidikan memegang peranan penting terutama dalam upaya membentuk watak bangsa melalui pengembangan kepribadian dan nilai-nilai yang diinginkan. Oleh sebab itu, di lembaga pendidikan khususnya madrasah perlu pendidik dan tenaga kependidikan yang profesional dalam meningkatkan kualitas madrasah. Menurut UU Sisdiknas No 20 tahun 2003 Pasal 1 ayat (6): "Pendidik adalah tenaga kependidikan yang berkualifikasi sebagai guru, dosen, konselor, pamong belajar, widyaiswara, tutor, instruktur, fasilitator, dan sebutan lainnya yang sesuai dengan kekhususannya, serta berpartisipasi dalam menyelenggarakan pendidikan". Pendidik merupakan salah satu kompenen yang mampu dan berhasil meningkatkan kemajuan madrasah dengan tugas utamanya mendidik, mengajar, membimbing serta mengevaluasi peserta didik baik jenjang dasar, menengah.

Sesuai pendapat Komariah \& Triatna (2006, p. 42) guru merupakan ujung tombak pendidik. Hal ini keberadaan pendidik menjadi aspek penting bagi keberhasilan sekolah/madrasah. Oleh sebab itu diperlukan pendidik yang mempunyai dedikasi terhadap pendidikan dengan didukung semua pihak khususnya madrasah memfasilitasi program-program yang mampu meningkatkan kualitas sumber daya khususnya pendidik. Menurut Dilshad \& Iqbal (2010, p. 408) "Teacher educators, being key stakeholders, play important role in reforming and improving quality of teacher education programmes". Pendidikan guru, menjadi stakeholder kunci, serta memainkan peranan penting dalam memperbaiki dan meningkatkan kualitas dalam program tenaga pendidik. Oleh karena itu, pendidik diharapkan meningkatkan kualitas kompetensi dengan mengikuti program-program yang diselenggarakan madrasah maupun dinas pendidikan.

Sedangkan menurut Chauhan \& Sharma (2015, p. 80) "Concept of teacher education - it is well known that the quality and extent of learner achievement are determined primarily by teacher competence, sensitivity and teacher motivation", konsep tenaga pendidik diketahui bahwa kualitas dan tingkat prestasi pelajar ditentukan terutama oleh kompetensi guru, sensitivitas dan motivasi guru. Sebagaimana kompetensi guru meliputi kompetensi pedagogik, kompetensi kepribadian, kompetensi sosial, dan kompetensi profesional. Oleh karena itu guru diharapkan memiliki keempat kompetensi tersebut dalam mewujudkan tujuan pendidikan. Sedangkan definisi tenaga kependidikan dalam UU Sisdiknas No 20 tahun 2003 pasal 1 ayat (5) "Tenaga kependidikan adalah anggota masyarakat yang mengabdikan diri dan diangkat untuk menunjang penyelenggaraan pendidikan". Dalam konteks pendidikan, pendidik dan tenaga kependidikan merupakan sumber daya manusia (SDM) potensial yang turut berperan dalam mewujudkan mutu pendidikan nasional.

Dalam konteks pendidikan, pendidik dan tenaga kependidikan merupakan sumber daya manusia (SDM) potensial yang turut berperan dalam mewujudkan mutu pendidikan nasional. Menurut Schuler, Dowling \& Smart, et al. (Heryati \& Muhsin, 2014, p. 57) menjelaskan bahwa "Human resources management (HRM) is the recogni- 
tion of the importance of an organization's workforce as vital human resources contributing to the goals of the organization, and the utilization of several functions and activities to ensure that they are used effectively and fairly for the benefit of the individual the organization, and society. Manajemen sumber daya manusia (SDM) memberikan pengakuan bahwa pentingnya tenaga kerja organisasi sebagai SDM utama yang memberikan konstribusi bagi pencapaian tujuan organisasi serta memberikan kepastian bahwa pelaksanaan fungsi dan kegiatan organisasi dilaksanakan secara efektif dan adil bagi kepentingan individu, organisasi dan masyarakat. Senada dengan pendapat Mondy, Noe \& Premeaux (1999, p. 4) bahwa "Human resources management (HRM) is the utilization of human resources to achieve organizational objectives". Jadi manajemen sumber daya manusia adalah pemanfaatan sumber daya manusia untuk mencapai tujuan organisasi.

Ada beberapa pendapat ahli mengungkapkan bahwa manajemen SDM berbeda dengan manajemen personalia. Menurut Heryati \& Muhsin (2014, pp. 56-57) "manajemen SDM berbeda dengan manajemen personalia, manajemen SDM menganggap bahwa karyawan adalah kekayaan (aset) utama organisasi yang harus dikelola dengan baik". Sedangkan "manajemen personalia menganggap karyawan sebagai salah satu faktor produksi yang harus dimanfaatkan secara produktif atau lebih menekankan pada sistem dan prosedur.

Manajemen SDM merupakan serangkaian sistem yang terintegrasi dan bertujuan untuk meningkatkan kinerja sumber daya manusia. Kulkarni (2012, p. 170) mengungkapkan bahwa "the human resource professional is emerging as a major creative constributor for organizational growth" sumber daya manusia yang profesional sebagai konstributor kreatif utama bagi pertumbuhan organisasi. Jadi diharapkan baik pendidik maupun tenaga kependidikan mempunyai keprofesionalitas dalam menyelesaikan berbagai tugas sehingga mampu meningkatkan kemajuan dalam organisasi pendidikan khususnya madrasah.
Menurut Bratton \& Gold (2000, p.14) "Human resource management is a body of knowledge and a set of practices that define the nature of work and regulate the employment relationship". Manajemen sumber daya manusia adalah bagian terpokok dari pengetahuan dan seperangkat praktek yang menegaskan dasar-dasar pekerjaan dan mengatur hubungan kerja. Jadi, Manajemen sumber daya manusia pada dasarnya merupakan integrasi keputusan yang membentuk hubungan antar tenaga kerja (pendidik dan tenaga kependidikan) dari segi pengelolaan SDM sehingga memberikan konstribusi terhadap kemampuan sumber daya manusia dan organisasi dalam mencapai tujuan. Sedangkan menurut Tim Dosen AP-UPI (2012, p. 231) "manajemen pendidik dan tenaga kependidikan adalah aktivitas yang harus dilakukan mulai dari pendidik dan tenaga kependidikan itu masuk ke dalam organisasi pendidikan sampai akhirnya berhenti, dengan melalui proses perencanaaan SDM, perekrutan, seleksi, penempatan, pemberian kompensasi, penghargaan, pendidikan dan latihan/pengembangan dan pemberhentian".

Jadi bisa disimpulkan bahwa manajemen pendidik dan tenaga kependidikan merupakan proses sumber daya manusia di lembaga organisasi pendidikan berupa tindakan-tindakan yang berupa perencanaan, perekrutan, seleksi, penempatan, kompensasi, penghargaan, pengembangan se-ta pemberhentian pendidik dan tenaga pendidik dalam mencapai tujuan yang diharapkan sebelumnya. Dalam penelitian ini yang dimaksud manajemen pendidik dan tenaga kependidikan difokuskan mulai dari proses perencanaan, perekrutan, penempatan dan pengembangan pendidik dan tenaga kependidikan di Madrasah Aliyah Negeri Kota Yogyakarta.

Dalam bidang pendidikan sumber daya manusia mempunyai peranan yang sangat penting dalam keberhasilan mencapai tujuan pendidikan. Secara mikro, fasilitas yang canggih dan lengkap belum merupakan jaminan keberhasilan pendidikan, tanpa diimbangi kualitas pendidik dan tenaga kependidikan yang akan meman- 
faatkan fasilitas tersebut. Oleh sebab itu, diperlukan perencanaan untuk memperoleh pendidik dan tenaga kependidikan yang berkualitas. Jahari \& Syarbini (2013, p. 34) menjelaskan bahwa "Perencanaan merupakan salah satu aspek yang memiliki peranan penting dalam menciptakan masa depan pendidikan Indonesia yang mampu menyelenggarakan layanan prima pendidikan nasional sehingga mampu membenuk insan cerdas komprehensif". Menurut Werther \& David (Tim Dosen AP-UNY, 2000 , p. 22) "Human resources planning is systematically forecast an organizations future demand for, and supplay of employees". Perencanaan sumber daya manusia adalah suatu perencanaan yang sistematik tentang perkiraan kebutuhan dan pengadaan atau pasokan tentang pekerja (pegawai).

Kegiatan rekrutmen merupakan cara yang dilakukan untuk memperoleh jumlah seseorang dalam melaksanakan tugas yang ditentukan. Menurut Jones \& Walters (2008, p. 126) rekrutmen adalah aktivitas yang terencana dalam menarik sejumlah individu berkualitas yang dibutuhkan untuk mengemban tugas-tugas yang ada di sebuah distrik operasional sekolah. Sedangkan menurut Denisi \& Griffin (AlZegaier, Al-Zu'bi \& Barakat. 2011, p. 69) "Recruitment process: the process of developing a pool of qualified applicants who are interested in working for the organization and from which the organization might reasonably select the best individual or individuals to hire for the employment". Terkait perekrutan pendidik dan tenaga kependidikan honorer di madrasah juga perlu menentukan kualifikasi tersebut agar memperoleh pegawai yang sesuai dengan tugas yang dibutuhkan dan keahlian yang dimiliki (the right man on the right place).

Penempatan dalam arti pembagian tugas pada para personil sekolah, baik yang lama maupun yang baru dalam lembaga pendidikan harus dilakukan oleh kepala sekolah. Menurut Rebore (2011, p. 159) "the placement of employees within the school system is the responsibility of the superintendents of schools". Menurut Tim Dosen AP-UNY (2000, p. 39) prinsip dasar penempatan dan penugasan pegawai adalah kesesuaian tugas dengan kemampuan yang dimiliki pegawai tersebut (The right man on the right place). Jadi, di dalam proses penempatan latar belakang pendidikan, keterampilan yang dimiliki baik pendidik maupun tenaga kependidikan harus sesuai dengan jabatan atau pekerjaan yang ditetapkan.

Dalam proses pembinaan, pengembangan pendidik dan tenaga kependidikan merupakan usaha yang dilakukan demi memajukan dan meningkatkan produktivitas kerja. Menurut Tim Dosen AP-UNY (2000, p. 41) "Pembinaan adalah semua upaya yang dilakukan oleh lembaga di dalam mempertahankan para personel untuk tetap berada di lingkungan organisasi dan mengupayakan pula kedinamisan keterampilan, pengetahuan, serta sikapnya agar mutu kerjanya bisa tetap dipertahankan. Sesuai dengan amanat undang-undang dalam mengembangkan profesi pendidik dan tenaga kependidikan, maka perlu adanya pelatihan dan pengembangan profesi. Tujuan kegiatan pembinaan menurut Heryati \& Muhsin (2014, p.67) untuk meningkatkan kemampuan setiap tenaga kependidikan yang meliputi pertumbuhan keilmuan, wawasan berpikir, sikap terhadap pekerjaan dan keterampilan dalam pelaksanaan tugas sehari-hari sehingga produktivitas kerja dapat ditingkatkan.

\section{Metode Penelitian}

Penelitian ini menggunakan pendekatan kualitatif dengan jenis fenomenologi. Penelitian ini dilakukan di Madrasah Aliyah Negeri di Kota Yogyakarta. Sedangkan pelaksanaan penelitian ini mulai $17 \mathrm{Fe}$ bruari sampai 20 Mei 2015. Dalam menentukan sumber data dilakukan dengan menggunakan metode purposive sampling. Sumber data dalam penelitian meliputi: Kepala Madrasah, Kepala TU, Guru, Kepala Laboratorium IPA, Kepala Laboratorium Komputer, dan Laboran Perpustakaan.

Teknik pengumpulan data yang digunakan dalam metode kualitatif ini adalah wawancara dan analisis dokumen. 
Wawancara yang dilakukan dalam penelitian ini adalah wawancara secara mendalam (indepth interview) yang bertujuan untuk menggali informasi terkait perencanaan, perekrutan, penempatan dan pengembangan pendidik dan tenaga kependidikan. Sedangkan analisis dokumen digunakan untuk memperoleh informasi yang bersifat tertulis (data sekunder) berkaitan sasaran program madrasah, strategi pengembangan pendidik dan tenaga kependidikan, dan kegiatan program pengembangan pendidik dan tenaga kependidikan MAN di Kota Yogyakarta.

Dalam penelitian kualitatif manusia atau peneliti sendiri yang menjadi instrumen penelitian yang utama. Instrumen yang digunakan dalam penelitian ini adalah peneliti itu sendiri yaitu pada saat permasalahan belum jelas dan pasti, maka yang menjadi instrumen adalah peneliti sendiri. Tetapi setelah masalah yang telah dipelajari jelas, maka dikembangkan suatu instrumen. Instrumen yang dikembangkan adalah pedoman wawancara. Pedoman wawancara yang dibuat adalah pedoman wawancara mendalam (indepth interview) untuk memperkuat dokumentasi.

Keabsahan data yang dilakukan dalam penelitian ini menggunakan kredibilitas, dependabilitas dan konfirmabilitas (Nasution, 2003, p. 114). Kredibilitas (credibility) adalah seberapa besar data yang didapatkan dapat dipercaya dan diterima kebenarannya, yaitu dengan cara meningkatkan ketekunan dan menggunakan triangulasi sumber dan teknik. Triangulasi disini yaitu melakukan cross check antar responden (triangulasi sumber) dan cross check antar teknik pengumpulan data (triangulasi teknik) untuk mendapatkan data yang valid dan kredibel. Dependabilitas (Dependability) adalah konsisten, yaitu memberikan hasil yang konsisten atau kesamaan hasil sehingga dapat dipercaya. Penelitian ini menggunakan instrument pengumpulan data berdasarkan konsep-konsep yang digunakan dan dikonsultasikan dengan pembimbing. Dan konfirmabilitas (Komfirmability) adalah pembuktian kebenaran yang dilakukan untuk menguji hasil penelitian yang dilakukan dengan cara membicarakan hasil penelitian dengan responden untuk memastikan data atau informasi yang akan ditulis dalam laporan penelitian sudah sesuai dengan kenyataan.

Teknik analisis data untuk masingmasing lokasi penelitian yang digunakan dalam peneltian ini mengadopsi dari teknik analisis data yang diungkapkan oleh Miles \& Huberman (Sugiyono, 2014, p. 404). Teknik analisis data dilakukan secara interaktif dan berlangsung secara terus menerus sampai tuntas, sehingga datanya sudah jenuh. Kegiatan analisis data pada penelitian ini yaitu dimulai dari pengumpulan data, reduksi data, display data, dan kesimpulan/verifikasi.

\section{Hasil Penelitian dan Pembahasan}

Hasil penelitian ini terkait perencanaan, perekrutan, penempatan, pengembangan pendidik dan tenaga kependidikan honorer di Madrasah Aliyah Negeri Kota Yogyakarta.

Data hasil penelitian terkait perencanaan pendidik dan tenaga kependidikan honorer menunjukkan bahwa dalam memperoleh pendidik honorer yang memiliki standar sesuai ketentuan pemerintah. Maka, perencanaan perekrutan pendidik honorer di MAN Kota Yogyakarta melalui analisis kebutuhan, analisis jabatan, analisis beban kerja kemudian bisa diketahui lakukan analisi kelebihan dan kekurangan pendidik. Sedangkan perencanaan perekrutan tenaga kependidikan honorer di MAN Kota Yogyakarta melalui analisis kebutuhan, analisis jabatan, analisis beban kerja, serta mampu menentukan kelebihan dan kekurangan tenaga kependidikan

Hasil penelitian di MAN Kota Yogyakarta, bisa dilihat pada teori yang dipaparkan oleh Nawawi (2000, p. 136) menjelaskan "Perencanaan sumber daya manusia dengan berorientasi pada hasil analisis pekerjaan, agar pekerja yang diperlukan dapat dipenuhi, baik dari segi kuantitatif (jumlahnya) maupun kualitatif (kualitasnya)". Didukung pula pendapat Mondy, Noe \& Premeaux (1999, p.148) mengung- 
kapkan bahwa "Human resource planning $(H R P)$ is the process of systematically reviewing human resources requirements to ensure that the required number of employeers, with the required skills, are available when they are needed. Dalam sebuah organisasi madrasah agar memperoleh tenaga pendidik dan tenaga kependidikan honorer yang benar sesuai dengan kebutuhan, titik tolak yang tidak boleh dilupakan, meliputi tujuan dan sasaran strategik yang ingin dicapai, memiliki kemampuan (skill) dan mampu berkarya dalam sebuah madrasah, kemudian perlu adanya kebijakan yang jelas. Misalnya terkait tentang adanya lowongan pekerjaan, pengisian jabatan.

Jadi, bisa disimpulkan bahwa dalam sebuah manajemen pendidik dan tenaga kependidikan honorer dibutuhkan perencanaan perekrutan yang baik. Sebuah lembaga pendidikan di madrasah, perencanaan sumber daya manusia khususnya pendidik dan tenaga kependidikan honorer sangat penting terkait penentuan kebutuhan baik jumlah dan kualifikasi dalam penempatan jabatan sehingga mampu menyelenggarakan aktivitas sasaran program madrasah yang baik terkait masa depan lembaga tersebut.

Dalam manajemen pendidik dan tenaga kependidikan, perencanaan perekrutan pendidik dan tenaga kependidikan honorer merupakan sebuah usaha untuk menjalankan proses perencanaan sehingga dapat berjalan dengan baik dan matang sehingga dapat menghasilkan kualitas pendidik dan tenaga kependidikan yang memuaskan sesuai dengan harapan yang dinginkan. Perencanaan pendidik dan tenaga kependidikan mempunyai peranan penting dalam keberhasilan mencapai tujuan pendidikan. Fasilitas sarana dan prasarana yang canggih dan lengkap belum merupakan jaminan memperoleh keberhasilan pendidikan tanpa diimbangi kualitas pendidik dan tenaga kependidikan yang akan mempergunakan fasilitas sarana dan prasarana tersebut. Sesuai dengan pendapat Walker (Hafeez \& Aburawi, 2013, p. 231) “...had suggested that through HRP, management is able to develop and deploy the right people at the right places at the right times to fulfill both organizational and individual objectives" Oleh karena itu, diperlukan manajemen perencanaan perekrutan dalam upaya memperoleh pendidik dan tenaga kependidikan yang berkualitas dan sesuai kebutuhan yang ditetapkan.

Menurut Siagian (2008, p. 45) perencanaan sumber daya manusia pun perlu diawali dengan kegiatan inventarisasi tentang sumber daya manusia yang sudah terdapat dalam organisasi. Sesuai dengan hasil penelitian di MAN Kota Yogyakarta, bisa dikaitkan dengan teori Siagian (2008, p. 45) bahwa perencanaan perekrutan di MAN Kota Yogyakarta dalam memperoleh pendidik honorer melalui analisis kebutuhan, melakukan analisis jabatan, melakukan analisis beban kerja, melakukan analisis kelebihan dan kekurangan pendidik. Sedangkan untuk tenaga kependidikan honorer juga melalui analisis kebutuhan, madrasah melakukan analisis jabatan, madrasah melakukan analisis beban kerja, madrasah melakukan analisis kelebihan dan kekurangan pendidik dan tenaga kependidikan, melakukan pembagian tugas pendidik dan tenaga kependidikan.

Data hasil penelitian terkait perekrutan pendidik dan tenaga kependidikan honorer menunjukkan bahwa madrasah menentukan kualifikasi. Kualifikasi pendidik honorer meliputi di MAN Kota meliputi: kualifikasi guru minimal jenjang S1, guru memenuhi tingkat kewenangan dan kesesuaian berdasarkan sertifikat pendidik, guru diharapkan memiliki sertifikat kompetensi, guru mampu menggunakan ICT dalam PBM dengan berbasis internet dan model Blogger, kesesuaian latar belakang pendidikan harus sesuai dengan mata pelajaran yang diampu, memiliki pengetahuan dan pengalaman yang dibutuhkan.

Sedangkan untuk kualifikasi tenaga kependidikan honorer di MAN Kota Yogyakarta bisa disimpulkan bahwa kualifikasi tenaga kependidikan meliputi: kualifikasi jenjang pendidikan minimal SMA, diutamakan memiliki bidang pendidikan (bidang administrasi, akuntasi, keperpustakaan, komputer), memiliki pengalaman 
kerja minimal 5 tahun, memiliki sertifikat (TU- Sarana Prasarana-Kesekratariatan Teknik Komputer: sertifikat komputer, administrasi keuangan dan akuntasi: sertifikat akuntan minimal D3, Pustakawan: sertifikat pustakawan), menguasai pengelolaan keuangan, administrasi sarana prasarana, kesekretariatan berbasis IT, kesesuaian latar belakang pendidikan dengan jabatan yang dibutuhkan.

Sesuai dengan hasil penelitian kualifikasi di MAN Kota Yogyakarta di atas, sesuai dengan teori 10 kualifikasi yang menjadi dasar dalam seleksi, menurut Tim Dosen AP-UNY (2000, p. 37) adalah mempunyai keahlian, mempunyai pengalaman, menentukan umur bagi calon pegawai, menentukan jenis kelamin, jenjang pendidikan, keadaan fisik dari calon pegawai, tampang dari calon pegawai, mempunyai bakat, dilihat dari watak, misalnya temperamen, dan dilihat dari karakter.

Bisa disimpulkan bahwa dalam perekrutan pendidik dan tenaga kependidikan honorer penting menentukan kualifikasi yang diterapkan di MAN Kota Yogyakarta meliputi: jenjang pendidikan, mempunyai keahlian, mempunyai pengalaman, memiliki bakat, serta jenis kelamin dan umur yang harus diketahui dalam proses perekrutan pendidik dan tenaga kependidikan honorer, terkait keadaan fisik, tampang serta karakter merupakan pendukung dalam perekrutan.

Dalam melaksanakan seleksi bagi calon tenaga pendidikan dapat ditentukan dasar kualifikasi yang mana diperlukan bagi jabatan yang akan dibutuhkan, sehingga bisa menentukan seseorang yang cocok dengan keahlian yang dimiliki. Sesuai dengan pendapat Armstrong (2006, p. 409) "requirement is preparing job descriptions and specifications, deciding terms, and conditions of employment". Rekrutmen merupakan proses pengumpulan calon pemegang jabatan yang sesuai dengan rencana pegawai untuk menduduki suatu jabatan tertentu. Hal ini berdampak pada kemampuan dalam menyelesaikan tugasnya sebagai pendidik dan tenaga kependidikan honorer di madrasah. Oleh karena itu, diper- lukan proses manajeman yang baik terkait perekrutan pendidik dan tenaga kependidikan honorer sehingga mampu menyelesaikan tugas pokok dan fungsi yang ada di madrasah.

Menurut Siagian (2008, p. 137) Perencanaan perekrutan terdiri dari paling sedikit delapan langkah yang bisa ditempuh. Ke delapan langkah tersebut meliputi: penerimaan surat lamaran, penyelenggaraan ujian, wawancara seleksi, pengecekkan latar belakang pelamar dan surat-surat referensinya, evaluasi kesehatan, wawancara oleh manajer yang akan menjadi atasan langsungnya, pengenalan pekerjaan, dan keputusan atas lamaran

Teori yang dipaparkan Siagian di atas dengan keadaan di lapangan yaitu MAN Kota Yogyakarta maka bisa diambil kesimpulan bahwa menentukan kualifikasi bagi pendidik dan tenaga kependidikan honorer adalah untuk menentukan seseorang pegawai dalam menyelesiakan tugas dari madrasah sehingga tujuan tercapai. Madrasah melakukan proses seleksi dan menentukan kualifikasi yang sudah ditentukan tersebut, berkaitan langsung dengan pekerjaan atau jabatan yang akan dilakukan selama bekerja di MAN Kota. Sedangkan menentukan kualifikasi secara langsung memberikan gambaran yang akurat tentang diri pendidik dan tenaga kependidikan honorer yang bersangkutan dalam menyelesaikan tugas pokok dan fungsi yang ditentukan.

Dengan melakukan perekrutan, pihak madrasah menentukan kualifikasi yang dijadikan acuan baik pendidik maupun tenaga kependidikan honorer. Hal tersebut dilakukan agar mampu menemukan seseorang yang sesuai dengan jabatan yang diharapkan dan mempunyai kinerja yang bagus dalam menyelesaikan tugas. Sesuai pendapat Byars \& Rue (1991, p. 168) "the process of choosing from among available applicants the individuals who are most likely to successfully perform a job". Oleh karena itu, bagi madrasah maupun lembaga pendidikan yang ingin melakukan perekrutan pegawai honorer, sebaiknya menentukan kualifikasi dasar sehingga mampu mene- 
mukan sseorang yang sesuai dengan jabatan atau posisi yang dibutuhkan dengan bidang keahlian yang dimiliki.

Data hasil penelitian terkait penempatan pendidik menunjukkan bahwa MAN Kota Yogyakarta, bisa disimpulkan bahwa kesesuaian latar belakang dan penempatan pendidik sudah memenuhi ketentuan UU Guru dan Dosen tahun 2005 pasal 7 ayat 1c tentang profesionalitas bahwa profesi guru dan profesi dosen merupakan bidang pekerjaan khusus yang dilaksanakan berdasarkan prinsip memiliki kualifikasi akademik dan latar belakang pendidikan sesuai dengan bidang tugas. Bahwa hasil penelitian tentang kesesuaian latar belakang pendidikan dan penempatan di MAN Kota Yogyakarta sebagai berikut: pendidik $90 \%$ dalam penempatan pendidik sudah sesuai latar belakang pendidikan dengan mata pelajaran yang diampu, pendidik berstatus PNS berkisar 89\%, sedangkan Honorer $11 \%$, pendidik sudah sertifikasi sesuai dengan SIM (Surat Izin Mengajar) akan tetapi masih ada mismatch dengan latar belakang dengan penempatan, masih ada jam tambahan bagi pendidik dengan syarat harus serumpun, dan berprinsip pada prinsip the right man on the right place.

Sesuai dengan teori yang diungkapkan oleh Daniel, Sanda \& Midala (2014, p.66) "Placement is the process of putting people into certain position who have been selected for the job". Penempatan adalah proses menempatkan orang ke dalam posisi tertentu yang telah dipilih untuk pekerjaan tersebut. Jadi, di dalam proses penempatan latar belakang pendidikan, keterampilan yang dimiliki baik pendidik maupun tenaga kependidikan harus sesuai dengan jabatan atau pekerjaan yang ditetapkan. Senada dengan Tim Dosen AP-UNY (2011, p. 70) bahwa prinsip dasar penempatan dan penugasan pegawai adalah kesesuaian tugas dengan kemampuan yang dimiliki pegawai (the right man on the right place).

Penempatan merupakan pembagian tugas para personil sekolah baik tenaga pendidik yang lama maupun yang baru. Oleh karena itu, hasil lapangan terkait penempatan pendidik, latar belakang pendi- dikan dengan materi yang diampu atau tugas jabatan merupakan salah satu acuan dalam penempatan pendidik. Dengan mempertimbangkan kesesuaian latar belakang pendidikan dengan penempatan ini akan meminimalis kesenjangan dalam penguasaan materi yang akan disampaikan ke peserta didik. Dari hasil penelitian di lapangan masih ada mismatch teacher (guru yang tidak sesuai dengan latar belakang pendidikan) masih terjadi di dalam madrasah. Sistem penempatan pendidik di MAN Kota Yogyakarta sudah memakai prinsip the right man on the right place, dimana madrasah melakukan penarikan atau perekrutan pendidik sesuai analisis jabatan atau kedudukan yang sudah ditentukan. Oleh sebab itu, kesesuaian tugas dengan kemampuan yang dimiliki pendidik honorer baru perlu diperhatikan kesesuaian latar belakang pendidikan tersebut.

Data hasil penelitian terkait pengembangan pendidik dan tenaga kependidikan menunjukkan bahwa MAN Kota Yogyakarta, dari hasil lapangan bisa disimpulkan bahwa kegiatan pengembangan di MAN Kota Yogyakarta sudah melakukan pengembangan secara maksimal dalam meningkatkan kualitas pendidik dan tenaga kependidikan. Dalam mencapai visi misi madrasah, adapun pengembangan yang secara garis besar sebagai berikut: pertemuan guru dalam rumpun mata pelajaran (MG$\mathrm{MP})$, pelatihan PTK dan peningkatan kualitas guru IPS, IPA, Bahasa dan Agama, workshop penelitian ilmiah dan peningkatan pembelajaran guru, pelaksanaan pengembangan diri dalam MGMP Kemenag dan Dikbud, pendidikan dan pelatihan multimedia, pendampingan PTK dari LPMP dan PT, pelatihan spiritual quantum learning (SQL), pelatihan strategi pembelajaran $e$ learning, studi lanjut, kegiatan K3MA (Sosialisasi, Bimbingan teknis, kegiatan kompetisi madrasah, seminar/lokakarya), pengembangan sistem informasi madrasah (Sisma). Sedangkan kegiatan pengembangan tenaga kependidikan di MAN Kota Yogyakarta: madrasah melakukan kolaborasi dengan berbagai instansi negeri maupun swasta, dalam hal pengembangan tenaga 
kependidikan, misalnya (pustakawan madrasah kolaborasi dengan perpustakaan daerah), diklat, seminar, melakukan pelatihan baik mendatangkan tenaga ahli dari kampus di Yogyakarta misalnya UGM, UIN, UNY, AKPRIND, menjalin kerja sama dengan madrasah-madrasah, menjalin kerja sama lewat jejaring sosial, pengenalan IT yang dilangsung diatur Kanwil dan Kemenag, misalnya ilmu pengetahuan dan teknologi (IPTEK) sehingga tidak gagap terkait informasi dan teknologi terbaru, selain itu adanya briefing setiap dua minggu sekalu setiap hari senin. Adanya rapat koordinasi terkait tugas-tugas pokok dan fungsi yang harus diselesaikan, Outbound, adanya pengembangan yang dilakukan dengan melalui forum media sosial, kepala madrasah juga mempunyai harapan untuk menyeimbangkan pengembangan pengembangan skill (sains) maupun softskill (hati) melalui pengajian.

Sesuai dengan teori yang diungkapkan Tim Dosen AP-UNY (2000, pp .59-61) bahwa secara umum kegiatan pengembangan meliputi dua bentuk yaitu bentuk latihan (training) dan bentuk pendidikan (education). Pendidik dan tenaga kependidikan merupakan sumber daya terpenting yang dimiliki dalam sebuah organisasi khususnya di madrasah. Oleh karena itu, pengembangan sangat penting dalam meningkatkan dan mempertahankan para pendidik dan tenaga kependidikan agar tetap eksis dalam lingkungan organisasi baik keterampilan (skill), pengetahuan (kompetensi), sikap dan perbuatan (baik afektif maupun psikomotorik) agar mampu mempertahankan dan meningkatkan kinerja yang dimiliki. Senada dengan Chow (2004, p.635) bahwa "training is an important investment in human capital to upgrade skill levels, and makes up for the lack of experienced and well-qualified staff', pelatihan adalah sebuah investasi penting bagi manusia untuk meng-upgrade tingkat keahlian, dan membuat staf mempunyai berpengalaman serta berkualitas baik.

\section{Simpulan}

Berdasarkan hasil penelitian dan pembahasan yang telah disjajikan maka dapat disampaikan beberapa simpulan sebagi berikut. Pertama, manajemen pendidik dan tenaga kependidikan honorer di MAN Kota Yogyakarta, terkait dalam melakukan perencanaan pendidik dan tenaga kependidikan honorer yang berkualitas dengan cara mengusulkan dari bottom-up yaitu dari madrasah ke Kantor Wilayah Kementrian Agama. Pertimbangan melalui tiga analisis yaitu analisis kebutuhan, analisis jabatan, analisis beban kerja, sehingga mampu dilakukan analisis kelebihan dan kekurangan.

Kedua, dalam melakukan perekrutan pendidik honorer dengan mempertimbangkan kualifikasi penerimaan sehingga mampu memperoleh pendidik yang berkompeten sesuai dengan mata pelajaran yang diampu; kualifikasi pendidik honorer tersebut meliputi: kualifikasi pendidik minimal jenjang S1, pendidik memenuhi tingkat kewenangan dan kesesuaian berdasarkan sertifikat pendidik, pendidik memiliki sertifikat kompetensi, pendidik mampu menggunakan ICT dalam PBM dengan berbasis internet dan model Blogger, memiliki pengetahuan dan pengalaman yang dibutuhkan. Sedangkan kualifikasi tenaga kependidikan yang memiliki skill dan keahlian yang dibutuhkan. Adapun kualifikasi tenaga kependidikan meliputi: kesesuaian latar belakang pendidikan dengan jabatan yang dibutuhkan, kualifikasi jenjang pendidikan minimal SMA, diiutamakan memiliki bidang pendidikan (bidang administrasi, akuntasi, keperpustakaan, komputer), memiliki pengalaman kerja, memiliki sertifikat (TU- Sarana Prasarana- Kesekretariatan- Teknik Komputer: sertifikat komputer, administrasi keuangan dan akuntasi: sertifikat akuntan minimal D3, Pustakawan: sertifikat pustakawan), menguasai pengelolaan keuangan, administrasi sarana prasarana, kesekretariatan berbasis IT.

Ketiga, dalam mencapai tujuan madrasah yang diharapkan, MAN Kota memperhatikan penempatan pendidik meliputi: pendidik berkisar $90 \%$ sudah sesuai latar 
belakang pendidikan dengan mata pelajaran yang diampu, Pendidik berstatus PNS berkisar $89 \%$, sedangkan Honorer $11 \%$, Pendidik sudah bersertifikasi sesuai dengan SIM (Surat Izin Mengajar) akan tetapi masih ada mismatch dengan latar belakang dengan penempatan, masih terdapat jam tambahan bagi pendidik dengan syarat harus serumpun, dan mengacu pada prinsip the right man on the right place.

Keempat, dalam kegiatan pengembangan MAN Kota Yogyakarta secara maksimal dalam meningkatkan kualitas pendidik sehingga visi misi madrasah tercapai, adapun pengembangan yang secara garis besar sebagai berikut: pertemuaan guru dalam rumpun mata pelajaran (MGMP), pelatihan PTK dan peningkatan kualitas guru IPS, IPA, Bahasa dan Agama, workshop penelitian ilmiah dan peningkatan pembelajaran guru, pelaksanaan pengembangan diri dalam MGMP Kemenag dan Dikbud, pendidikan dan pelatihan multimedia, pendampingan PTK dari LPMP dan PT, pelatihan spiritual quantum learning (SQL), pelatihan strategi pembelajaran $e$ learning, studi lanjut, kegiatan K3MA (Sosialisasi, Bimbingan teknis, kegiatan kompetisi madrasah, seminar/lokakarya), pengembangan sistem informasi madrasah (Sisma). Sedangkan dalam kegiatan pengembangan kegiatan pengembangan tenaga kependidikan di MAN Kota Yogyakarta meliputi: madrasah melakukan kolaborasi dengan berbagai instansi negeri maupun swasta, diklat, seminar, melakukan pelatihan baik mendatangkan tenaga ahli dari kampus di Yogyakarta seperti UGM, UIN, UNY, AKPRIND, menjalin kerja sama dengan madrasah-madrasah lain, menjalin kerjasama lewat jejaring sosial, Pengenalan IT yang dilangsung diatur Kanwil Kemenag, adanya briefing setiap dua minggu sekali, outbound, adanya pengembangan yang dilakukan dengan melalui forum media sosial, kegiatan pengajian.

Adapun saran yang dapat dikemukakan antara lain: (1) untuk Kepala Madrasah, agar melakukan studi lanjut bagi pendidik yang latar belakang pendidikan dengan mata pelajaran yang mengalami mismatch, terkait pembagian tugas pendidik dan tenaga kependidikan perlu penataan ulang sehingga pendidik tidak mengalami over supply (kelebihan kebutuhan) dan undersupply (kekurangan kebutuhan) jam mengajar; (2) untuk pendidik dan tenagakependidikan agar meningkatkan pengetahuan dan keterampilan dengan cara belajar mandiri, membaca, dan berdiskusi, ketika mengalami kesulitan dalam proses pembelajaran dan pengolahan data sehingga mampu menyelesaikan tugas pokok dan fungsi tugas yang sudah ditentukan.

\section{Daftar Pustaka}

Al-Zegaier, H., Al-Zu'bi, H. A., \& Barakat. S. (2011). Investigating the link between web data mining and strategic human resources planning. Published by Canadian Center of Science and Education Vol. 4, No. 3. Amman, Jordan. Applied Science University; May.

Armstrong, M. (2006). A handbook of human resource management practice. London and Philadelphia: Kogan Page.

Bratton, J., \& Gold, J. (2000). Human resource management: Theory and practice. New Jersey: Macmillan Press.

Byars, L. L., \& Rue, L. W. (1991). Human resource management. United States of America: Richard D. Irwin, Inc.

Castetter, W. B. (1996). The human research for educational administration. New Jersey: A. Simon \& Schuster Company.

Certo, S. C., \& Certo, T. (2012). Modern management: Concepts and skill. London: Library of Congress Cataloging.

Chow, I. H. (2004). The impact of institutional context on human resource management in three Chinese societies. Journal of Employee relation. $2004 ; 26$, ,6: ABI/inform complete.

Chauhan, A., \& Sharma, P. (2015). Teacher education and total quality management (TQM). The International 
Journal of Indian Psychology, Volume 2, Issue 2, Paper ID: B00330V2I22015.

Daniel, A., Sanda, A. A., \& Midala, A. S. (2014). Recruitment, selection and placement of human resource in adult education organisation: implications for the management of adult education Borno State Nigeria. Journal of Education and Practice. Vol.5, No.31

Dilshad, M., \& Iqbal, H. M. (2010). Quality indicators in teacher education programmes. Pakistan Journal of Social Sciences (PJSS), Vol. 30, No. 2 (December 2010), pp. 401-411.

Hafeez, K., \& Aburawi, I. (2013). Planning human resource requirements to meet target customer service levels. International Journal of Quality and Service Sciences. Vol. 5 No. 2, 2013, pp. 230-252.

Freedman, R. D., Cooper, C. L., \& Stumps, S. A. (1982). Management educations issues in theory, research and practice. New York: John Wiley \& Sons Ltd.

Heryati, Y., \& Muhsin, M. (2014). Manajemen sumber daya pendidikan. Bandung: Pustaka Setia.

Jahari, J., \& Syarbini, A. (2014). Manajemen madrasah: Teori, strategi, dan implementasi. Bandung: Alfabeta.

Jones, J. J., \& Walters, D. L (2008). Human resource management in education. Yogyakarta: Q-Media.

Komariah, A., \& Triatna, C. (2006). Visionary leadership. Jakarta: PT. Bumi Aksara.

Kulkarni, S. S. (2012). Human resource development in universities: a case study of Karnatak Universitas, Dharwad. International Journal of Organizational Behaviour \& Management Perspectives (C) Pezzottaite Journals. Volume:1, Number; 2.

Maimun, A., \& Fitri, A. Z. (2010). Madrasah unggulan: Lembaga pendidikan alternatif di era kompetitif. Malang: UIN Maliki Press.
Mondy, W., Noe, R. M., \& Premeaux, S. R. (1999). Human resource management. United State of America: Prentice Hall International.

Nasution, S. (2003). Metode penelitian naturalistik-kualitatif. Bandung: Tarsino.

Nawawi, H. (2000). Manajemen sumber daya manusia untuk bisnis yang kompetitif. Yogyakarta: Gajah Mada University Press.

Purwanto, M. N. (2007). Ilmu praktis teoretis dan praktis. Bandung: PT. Remaja Rosdakarya.

Rebore, R. W. (2011). Human resources administration in education: A management approach. New Jersey: Pearson Education.

Republik Indonesia. (2009). Undang-undang RI Nomor 14, Tahun 2005, tentang Guru dan Dosen.

Republik Indonesia. (2003). Undang-Undang RI Nomor 20, Tahun 2003, tentang Sistem Pendidikan Nasional.

Sharma, S. L. (2009). Educational management. New Delhi: Global India.

Siagian, S. P. (2008). Manajemen sumber daya manusia, Jakarta: Bumi Aksara.

Sugiyono. (2014). Metode penelitian manajemen. Bandung: Alfabeta.

Sunhaji. (2008). Manajemen madrasah. Yogyakarta: Grafindo Litera Media.

Tim Dosen Administrasi Pendidikan Universitas Negeri Yogyakarta. (2000). Manajemen tenaga pendidikan. Yogyakarta: FIP UNY.

Tim Dosen Administrasi Pendidikan Universitas Negeri Yogyakarta. (2011). Manajemen pendidikan. Yogyakarta: UNY Press.

Tim Dosen Administrasi Pendidikan Universitas Pendidikan Indonesia. (2012). Manajemen pendidikan. Bandung: Alfabeta. 